\title{
ANALISIS KEMAMPUAN BERPIKIR KREATIF SISWA DALAM MENYELESAIKAN SOAL PADA MATERI PEMANASAN GLOBAL BERDASARKAN PRESTASI SISWA
}

\author{
Luluk Rachmatul Yasiro' ${ }^{1}$, Fitria Eka Wulandari ${ }^{*}{ }^{*}$, Fahmi $^{3}$ \\ ${ }^{1,2}$ Pendidikan IPA FPIP Universitas Muhammadiyah Sidoarjo, Indonesia \\ e-mail: fitriaekawulandari@umsida.ac.id \\ ${ }^{3}$ Magister Keguruan IPA, Program Pascasarjana, Universitas Lambung Mangkurat, Banjarmasin, Indonesia \\ e-mail: ibnusuwandy@gmail.com
}

$\begin{array}{lll}\text { Submit } & : 10-02-2021 & \text { Revision : 23-03-2021 } \\ \text { Accepted } & : 26-03-2021 & \text { Published : 01-04-2021 }\end{array}$

*Corresponding author: Fitria Eka Wulandari

\begin{abstract}
Abstrak: Kemampuan berpikir kreatif merupakan kemampuan yang harus dimiliki oleh siswa untuk menemukan atau menciptakan hal baru yang berguna baginya dalam proses belajar. Siswa dengan prestasi yang tinggi belum tentu memiliki kreatifitas yang tinggi pula. Penelitian ini bertujuan untuk mengungkap kemampuan berpikir kreatif siswa pada materi pemanasan global berdasarkan prestasi siswa. Metode penelitian ini menggunakan metode kualitatif dengan pendekatan fenomenologi. Lokasi penelitian dilaksanakan di SMP Negeri 1 Jabon, Dukuh Sari Jabon Sidoarjo. Teknik pengumpulan data yang digunakan yakni tes dan wawancara. Subjek dalam penelitian ini adalah 3 siswa berprestasi di kelas VIII dengan peringkat 1-3. Hasil penelitian menunjukkan bahwa siswa peringkat 1 kreatif, siswa peringkat 2 cukup kreatif, dan siswa peringkat 3 sangat kreatif.
\end{abstract}

Kata kunci: kemampuan berpikir kreatif, materi pemanasan global, prestasi

\section{ANALYSIS OF STUDENTS CREATIVE THINKING ABILITY IN COMPLETING PROBLEMS ON GLOBAL HEATINGMATERIALS BASED ON STUDENT ACHIEVEMENT}

\begin{abstract}
The ability to think creatively is an ability that students must have to find or create new things that are useful for student in the learning process. Students with high achievement do not necessarily have high creativity either. This study aims to reveal students creative thinking skills in global warming material based on student achievement. This research method uses qualitative methods with a phenomenological approach. The research location was conducted at SMP Negeri 1 Jabon, Dukuh Sari Jabon Sidoarjo. Data collection techniques used are tests dan interviews. The subjects in this study were 3 outstanding students in class VIII with ratings 1-3. The results showed that students in rank 1 were creative, students in rank 2 were quite creative, and students in rank 3 were very creative.
\end{abstract}

Keywords: creative thinking ability, global warming material, achievement

\section{PENDAHULUAN}

Berpikir kreatif adalah kemampuan yang harus dimiliki siswa untuk menemukan dan menciptakan sesuatu hal yang baru, cara-cara baru, model baru yang berguna bagi siswa dalam proses belajar (Nurjan, 2018). Berpikir kreatif merupakan sebuah kebiasan dari pikiran yang dilatih dengan memperhatikan intuisi, menghidupkan imajinasi, mengungkapkan hal baru yang perlu digali, karena berpikir kreatif merupakan salah satu tujuan pendidikan nasional (Amalia, 2017). Oleh karena itu berpikir kreatif sangat dibutuhkan untuk memecahkan masalah yang tidak terduga dalam kehidupan sehari-hari, 
Yasiro, L.R. \& Wulandari, F.E., \& Fahmi. (2021). Analisis Kemampuan Berpikir Kreatif Siswa dalam Menyelesaikan Soal pada Materi Pemanasan Global di Smpn 1 Jabon Berdasarkan Prestasi Siswa.

dan bagi siswa diharapkan mampu menyelesaikan masalah atau soal dengan berbagai ide tau gagasan yang luas.

Menurut Munandar (2014) berpikir kreatif menjadi salah satu kemampuan untuk memecahkan masalah, menemukan konsep dan menciptakan suatu hal baru dalam kegiatan belajar yang tercermin dalam kelancaran, kelenturan dan originalitas dalam berpikir dan berinteraksi. Berpikir kreatif dalam pembelajaran sangat penting terutama dalam pembelajaran Ilmu Pengetahuan Alam (IPA). IPA merupakan mata pelajaran yang mencari keterkaitan alam dengan konsep matematis, sehingga IPA merupakan suatu penemuan tentang konsep-konsep atau fakta-fakta yang ada (Fahmi, 2015; Khaerani dkk., 2020). Melalui pembelajaran IPA siswa akan mendapat pengetahuan untuk memecahkan permasalahan dalam kehidupan sehari-hari serta dapat menerapkannya dalam kehidupan nyata (Fahmi, 2016; Af'idayani dkk., 2018).

Hasil observasi yang dilakukan oleh peneliti di SMPN 1 Jabon terhadap kondisi siswa, diketahui bahwa setiap siswa memiliki perbedaan dalam penyelesaian soal. Keberagaman penyelesaian soal ada yang terpatok pada penyelesaian yang guru contohkan dan ada juga yang penyelesaiannya berdasarkan pada pengembangan pola fikir siswa sendiri. Pengembangan pola pikir siswa itu sendiri merupakan bagian dari keterampilan berfikir kreatif (Amalia, 2017). Tercapainya kemampuan berpikir kreatif dapat dipengaruhi oleh faktor yang mendukung dan faktor yang menghambat. Dengan adanya faktor tersebut guru harus menunjang siswa dengan menggunakan metode pembelajaran yang di sesuaikan oleh kurikulum 2013. Selain inovasi metode pembelajaran, kreatifitas siswa dalam menyelesaikan soal juga menjadi objek guru dalam penilaian.

Pemilihan subjek penelitian didasarkan pada tingkat keaktifan dan prestasi siswa. Keaktifan siswa dalam proses pembelajaran akan menyebabkan interaksi yang tinggi antara guru dengan siswa dan aktivitas tersebut dapat memberikan pengaruh yang baik terhadap pembentukan pengetahuan dan keterampilan yang mengarah pada peningkatan prestasi (Rahayu dkk., 2018; Zakiyah, 2018). Fahmi dan Irhasyurna (2019) mengungkapkan bahwa prestasi belajar yang dicapai seorang siswa erat kaitannya dengan tingkat intelegensi yang dimiliki. Siswa yang memiliki tingkat intelegensi tinggi akan lebih mudah menangkap, mencerna, dan memahami materi pelajaran (Santoso \& Wulandari, 2020).

Berdasarkan data di atas, penelitian ini dimaksudkan untuk mengungkap kemampuan siswa dengan peringkat 1, 2, dan 3 pada kelas unggulan yang ada di SMPN I Jabon, dengan tujuan untuk menganalisis kemampuan berpikir kreatif siswa dilihat dari tingkat prestasinya.

\section{METODE PENELITIAN}

Penelitian ini menggunakan metode kualitatif pendekatan fenomenologi. Almansyur (2012) menyatakan bahwa pendekatan fenomenologi ini memfokuskan pada pengalaman pribadi individu, subjek penelitiannya adalah orang yang mengalami langsung kejadian atau peristiwa yang terjadi. Kejadian atau peristiwa yang dimaksud di sini adalah siswa yang menjadi subjek penelitian sudah pernah menyelesaikan soal kreatif. Subjek dalam penelitian ini adalah 3 siswa berprestasi peringkat 1-3 dikelas VIII. Pada penelitian ini menggunakan triangulasi yaitu pengecekan data atau sumber dari berbagai cara atau waktu. Tri angulasi yang digunakan adalah triangulasi teknik yang dipilih untuk mencari kredibilitas hasil data (Lapau, 2012).

Teknik penelitian yang digunakan yaitu tes hasil belajar dan wawancara. Tes dan wawancara dilakukan dengan bertemu langsung dengan subjek. Tes yang dibagikan berisikan soal pada materi pembelajaran yang sudah dipelajari dan memuat 4 indikator kreatif yaitu kelancaran, keluwesan, keaslian, dan keterincian yang setiap indikator berisi 2 soal, sehingga jumlah soal yang diberikan adalah 8 soal.

\section{HASIL DAN PEMBAHASAN}

Pada indikator kelancaran, soal yang digunakan menerapkan sebuah contoh peristiwa permasalahan yang ada dikehidupan sehari-hari. Siswa peringkat 1, 2 dan 3 merasa sudah paham dengan soal yang diberikan akan tetapi pada saat mengerjakan soal, jawaban yang diberikan hanya 1 jawaban kecuali siswa peringkat 3. Secara umun, siswa tidak menyebutkan permasalahan apa saja yang ada pada informasi soal yang diberikan. Diberikan soal yang sama dengan perintah soal yang lebih jelas siswa belum mampu memberikan jawaban yang beragam.

Wawancara yang dilakukan peneliti menunjukkan bahwa siswa peringkat 1 dan 2 hanya mampu membahas satu pokok pemikiran dalam skala terbatas berdasarkan pengetahuan yang mereka miliki. Dalam hal ini siswa peringkat 1 dan 2 belum memenuhi kriteria berpikir kreatif pada indikator kelancaran, sedangkan siswa peringkat 3 memenuhi kriteria tersebut. Menurut Amalia (2017) aspek ke- 
lancaran terkait dengan cara siswa membangun ide dan mengacu pada beragamnya jawaban benar yang diberikan siswa.

Indikator yang selanjutnya yaitu keluwesan, siswa akan menggali dari informasi yang ada pada soal tentang faktor penyebab pemanasan global. Siswa pada soal di sini menjelaskan faktor penyebab bukan berasal dari permasalahan tetapi penyebab dari informasi. Diberikan soal yang sama, siswa peringkat 1 dan 3 sudah mampu memberikan jawaban dengan benar dan dengan berbagai macam jawaban dan penyelesaian yang berbeda, sedangkan siswa peringkat 2 belum mampu melakukan hal tersebut.

Siswa peringkat 1 dan 3 ketika tidak tahu materi yang dijelaskan oleh guru, mereka mencari informasi sendiri melalui internet atau media yang lain, sedangkan siswa peringkat 2 tidak. Menurut Suyidno dkk. (2019) aspek keluwesan berpikir mengarah kepada kemampuan siswa untuk memecahkan masalah dengan beragam cara penyelesaian yang berbeda. Dalam hal ini siswa peringkat 1 dan 3 sudah memenuhi kriteria indikator berpikir kreatif keluwesan, sedangkan siswa peringkat 2 belum.

Pada indikator keaslian, kepada siswa dituntut untuk menemukan ide baru dalam menyelesaikan suatu permasalahan, dan semua siswa pada indikator ini mampu melakukan hal tersebut. Menurut Nur (2014) kreatif adalah bagaimana cara siswa menyelesaikan berbagai permasalahan dan memberikan suatu jawaban yang sama melalui kombinasi pengetauhan yang dimiliki siswa, keterampilan atau cara berpikir yang sudah dipelajari oleh siswa.

Aspek yang selanjutnya yaitu keterincian, dalam hal ini subjek semua siswa juga mampu memberikan alasan serta langkah secara rinci atas ide yang diberikan. Pada wawancara yang dilakukan, siswa mampu memberikan jawaban dengan tepat sesuai yang diharapkan peneliti. Suyidno dkk. (2019) menjelaskan bahwa aspek keterincian terkait dengan kemampuan siswa untuk menjelaskan secara runtut, rinci dan saling terkait satu sama lain. Pada indikator ini, seluruh siswa mampu memenuhi indikator kerincian sesuai yang diharapkan.

Subjek peringkat 1 dikategorikan siswa kreatif karena dapat memenuhi 3 dari 4 indikator berpikir kreatif yang telah diujikan, siswa peringkat 2 dikategorikan cukup kreatif karena memenuhi 2 dari 4 indikator berpikir kreatif, dan siswa peringkat 3 dikategorikan sangat kreatif karena memenuhin seluruh indikator berpikir kreatif.

Hasil penelitian ini menunjukkan bahwa kemampuan berpikir kreatif siswa tidak hanya bergantung pada prestasi akademik siswa. Hal ini sejalan dengan penelitian yang dilakukan Amalia (2017) yang mengatakan bahwa seseorang yang memiliki intelegesi tinggi belum tentu kreatif. Karena kreatif menjurus ke penciptaan sesuatu yang baru bergantung pada kemampuan seseorang mendapatkan pengetahuan yang sudah umum diterima. Siswa dengan peringkat 3 sangat kreatif karena dia memiliki pengetahuan yang banyak dengan bertanya kepada guru dan menelaah informasi dengan menghubungkannya pada kehidupan nyata. Oleh karena itu, guru harus memberikan kesempatan dan kepercayaan kepada siswa agar mereka dapat mengeluarkan gagasan-gagasan yang baru serta inovasi dalam pembelajaran sehingga dapat meningkatkan dan mengembangkan kemampuan berpikir kreatif siswa (Kau, 2017).

\section{SIMPULAN}

Kemampuan berpikir kreatif siswa pada materi pemanasan global berada pada kategori kreatif, cukup kreatif dan sangat kreatif. Hal ini dikarenakan siswa memenuhi indikator berpikir kreatif yang telah dirumuskan. Kreativitas bisa terus dikembangkan dengan cara terus mencoba, mencari informasi lebih secara mandiri, dan bertanya jika tidak paham kepada guru.

\section{DAFTAR PUSTAKA}

Af'idayani, N., Setiadi, I., \& Fahmi. (2018). The Effect of Inquiry Model on Science Process Skills and Learning Outcomes. European Journal of Education Studies, 4 (12), 177-182. Doi: 10.5281/zenodo.1344846.

Amalia, L. (2017). Pengembangan Perangkat Pembelajaran Materi Pokok Zat Aditif dan Zat Adiktif Menggunakan Model Creatif Problem Solving untuk Melatihkan Keterampilan Berpikir Kreatif Peserta Didik SMP. Tesis. Program Stud Magister Keguruan IPA PPs ULM.

Almansyur, F \& Ghony, D. (2012). Metodologi Penelitian Kualitatif. Jogjakarta: Ar-Ruzz Media Antika. 
Yasiro, L.R. \& Wulandari, F.E., \& Fahmi. (2021). Analisis Kemampuan Berpikir Kreatif Siswa dalam Menyelesaikan Soal pada Materi Pemanasan Global di Smpn 1 Jabon Berdasarkan Prestasi Siswa.

Fahmi \& Irhasyuarna, Y. (2019). Pengantar Pendidikan: Manusia, Pendidikan, dan Perkembangan Zaman. Banjarmasin: Program Studi Magister Keguruan IPA PPs ULM.

Fahmi. (2015). Penggunaan Zat Pewarna pada Kain Sasirangan sebagai Sumber Belajar Ilmu Pengetahuan Alam. Proceeding International Seminar on Ethnopedagogy. FKIP Unlam Press.

Fahmi. (2016). Strategi Pembelajaran Contextual Teaching and Learning untuk Meningkatkan Keterampilan Berpikir Tingkat Tinggi. Prosiding Seminar Nasional Pendidikan IPA "Mengembangkan Keterampilan Berpikir Tingkat Tinggi Melalui Pembelajaran IPA”. S2 IPA Unlam Press. Banjarmasin, Indonesia. ISBN. 978-602-60213-0-4

Kau, M. (2017). Peran Guru dalam Mengembangkan Kreativitas Anak Sekolah Dasar. Proceeding Seminar dan Lokakarya Nasional Revitalisasi Laboratorium dan Jurnal Ilmiah dalam Implementasi Kurikulum Bimbingan dan Konseling Besbasis KKNI.

Khaerani, S.K., Utami, S.D., \& Mursali, S. (2020). Pengembangan Perangkat Pembelajaran IPA Berbasis Kearifan Lokal untuk Meningkatkan Hasil Belajar Kognitif Siswa. Journal of Banua Science Education (JBSE), 1 (1), 35-42. E- ISSN: 2745-7222. Doi: 10.20527/jbse.v1i1.2. http://jbse.ulm.ac.id/index.php/JBSE/issue/view/2

Lapau, B. (2012). Metode Penelitian Kesehatan: Metode Ilmiah Penulisan Skripsi, Tesis, dan Disertasi. Jakarta: Yayasan Pustaka Obor Indonesia

Munandar, U. (2014). Pengembangan Kreativitas Anak Berbakat. Jakarta: Rineka Cipta.

Nur, M. (2014). Berfikir Kretif. Surabaya: Universitas Negeri Surabaya.

Nurjan, S. (2018). Pengembangan Berpikir Kreatif. Journal Basic of Educatio, 3 (1).

Rahayu, A.B., Hadi, S., Istyadji, M., Zaini, M., Sholahuddin, A., \& Fahmi. (2018). Development of Guided Inquiry Based Learning Devices to Improve Student Learning Outcomes in Science Materials in Middle School. European Journal of Alternative Education Studies, 3 (2), 107-117. Doi: 10.5281/zenodo.2261027.

Satoso, B.P \& Wulandari, F.E. (2020). Pengaruh Pembelajaran Berbasis Proyek Dipadu dengan Metode Pemecahan Masalah pada Keterampilan Berpikir Kreatif Siswa. Journal of Banua Science Education (JBSE), 1 (1), 1-6. E- ISSN: 2745-7222. Doi: 10.20527/jbse.v1i1.3. http://jbse.ulm.ac.id/index.php/JBSE/issue/view/2

Suyidno., Nur, M., Yuniarti, L., \& Salam M.A. (2019). Creative Responsibility Based Learning: Kreatuif Pendidikannya, Dahsyat Peserta Didiknya. Banjarmasin: ULM Press.

Zakiyah, A. (2015). Hubungan Kreativitas Guru PAI dengan Keaktifan Belajar Siswa pada Bidang Studi PAI di SMP Wachid Hasyim 4 Surabaya. Tesis. UIN Sunan Ampel.

\section{UCAPAN TERIMA KASIH}

Terimakasih kepada kepala sekolah dan guru mata pelajaran IPA SMP Negeri 1 Jabon yang telah membantu dalam pelaksanaan penelitian ini, siswa SMP Negeri 1 Jabon yang telah bersedia menjadi subjek penelitian serta semua pihak yang membantu dalam kelancaran penulisan ini. 